\title{
Interesting Pausal Forms in the Speech of Muslims and Christians in Kufur-Kanna*
}

\author{
AMAL ZU'BI
}

\begin{abstract}
The aim of this paper is to describe the system of vocalic variants in pause pertaining to speakers of Arabic in Kuf ${ }^{\mathrm{r}}$-Kanna (AKK) and in this regard to determine the features that characterize the AKK. As in Nazareth, the incidence of pauses in AKK varies and depends on the content, the listener and the speaker's intentions. In AKK I detected pausal forms in the speech of middle-aged and elderly Muslims and elderly Christians. In addition to changes in consonants and vowel quality in their speech, in pausal position final syllables also undergo other modifications as compared to the contextual forms.

Unlike in Nazareth, four further types were identified in AKK: (1) lengthening of short vowels in final position: $-\mathrm{Cv}>-\mathrm{C} \overline{\mathrm{v}} \#,-\mathrm{CvC}>-\mathrm{C} \overline{\mathrm{v}} \mathrm{C}$; lengthening of normal and anaptyctic short vowels in final closed syllables: -CvC; (2) devoicing of voiced consonants in word-final position; (3) glottalization after consonants and vowels in word-final position; and (4) aspiration: addition of $(h)$ in pausal position where the word ends in long vowels.
\end{abstract}

Key words: Arabic dialects - Pausal forms - Syllables - Long vowels - Short vowels - Christians and Muslims.

\section{Kufur-Kanna ${ }^{1}$}

Kufur-Kanna is a village in Lower Galilee, about six kilometers northeast of the city center of Nazareth. In 1968 it was declared a local council. According to the Central Bureau of Statistics, ${ }^{2}$ as of December 2019, 22,751 residents live in Kufur-Kanna. 89.2\% of the residents of the village are Muslims, $10.7 \%$ are Christian (mainly Greek Catholic and

* I wish to thank Werner ARNOLD and Simon HOPKINS for reading earlier versions of this paper and discussing its contents with me.

1 Cf. AWAWDE 2008. The historical material about Kuf"r-Kanna originated from Wikipedia (see bibliography below). The reliability of the material was tested back to the sources from which the material was taken.

2 On the website of the Central Bureau of Statistics, 2019. 
Greek Orthodox), $0.1 \%$ are Druze.

Kuf ${ }^{u}$-Kanna has an industrial zone that employs hundreds of workers from the town and the region, with large factories and manufacturers of various products, such as solar and electricity plants, block factories and tire factories.

\subsection{History}

The ancient settlement Kanna is already mentioned in the Egyptian letters of Tall al'Amārna. During the First Temple period there was a Jewish settlement there, as well as during the Second Temple period. Josephus Flavius, who lived in the village, fortified it when he was governor of Galilee during the Great Revolt, archaeologists found evidence of which. After the destruction of the Second Temple, beginning with the Amoraim (sic) and throughout the Mishnaic and Talmudic periods, there was a Jewish settlement. In the Byzantine period, Christians also began settling there, and the remains of a church from the 6th century were discovered.

In the Middle Ages the settlement also is mentioned as a road station between Egypt and Syria, and in the sixteenth century as a flourishing and wealthy settlement in which the village had dyeing houses. According to the Turkish census conducted in 1555, 65 Jewish families lived in the town, some of them exiles from Spain, in addition to 375 Christian families. Apparently in the seventeenth century the Jewish settlement ended. In the 19th century the Catholic Church was built on the ruins of the ancient 6th century church and a Greek Orthodox church also was established in the settlement.

\subsection{Kufur-Kanna in Christianity}

Since the middle ages there is a wooden barrel which has been associated with the biblical account of Jesus changing water into wine at a wedding. ${ }^{3}$ Some researchers suggest Xirbat Qana a to the north of the Bet Netofa Valley as the site. The village has two nearby churches that commemorate the event-the Franciscan Catholic Church of the Marriage and the Greek Orthodox Church. There are three other churches in the village: (1) the Church of the House of Bartholomew, (2) the Franciscan Apostle and (3) the Church of the Melkite Quarter. In the south of the village a spring used to be the only source of water for the village. The place was admired by the pilgrims who pointed to it as the source from which the water was drawn to fill the urns at the wedding ceremonies of the poor.

At Dalman's time (1921) the consecration of Kuf ur-Kanna was associated with the Franciscan settlement of Nazareth in 1620. In the 19th century, the inhabitants established their church in the village. In the War of Independence Kuf ${ }^{4} r-K a n n a$ was the center of Arab gangs that raided Jewish settlements. Their control over the important roads in the heart of Galilee disrupted Jewish transportation and in March 1942, a military unit moved out of Ilaniya on the village. In 1948 after the conquest of Nazareth, Kuf ur-Kanna also surrendered without a battle.

3 So it is in the Bible: John 2:1-11.

• 21 (2021): 121-136 


\section{Fieldwork and informants}

The pausal forms in AKK are similar to those that occur in Nazareth: Lowering of short vowels $i$ u e o in final syllable, lengthening of short vowels $-\mathrm{Cv}>-\mathrm{C} \bar{v} \#,{ }^{4}-\mathrm{CvC}>-\mathrm{C} \overline{\mathrm{V}} \mathrm{C}$ in final position, diphthongization, raising of low vowels in the syllable $-\mathrm{C} \overline{\mathrm{v}} \mathrm{C} \#$ and addition of (h) in pausal position where the word ends in consonant or short vowel. ${ }^{5}$

In Nazareth (ZU'BI 2017) pausal forms occur in the speech of middle-aged and elderly Muslims and elderly Maronites: In addition to changes in vowel quality in their speech, in pausal position final syllables also undergo other modifications relative the form in normal speech (context form). For example, lengthening, diphthongization and aspiration (in cases of vowel changes) occur as a secondary step after a change in the vowel, and they relate with it. ${ }^{6}$ It is worth noting that, in the speech of these groups, the closed syllables often undergo only a change of vowel quality, but this may also be accompanied by lengthening. Finaly open syllables have changes in vowel quality and secondary changes such as diphthongization. ${ }^{7}$

In Nazareth, in the speech of Muslims and Maronite Christians, words occurring in pausal position may undergo different kinds of change according to syllable type. Five types were identified: (1) lowering of $i>e \#$ and $u>o \#$; (2) lengthening of $(u>) o>\bar{o} \#$, $(i>) e>\bar{e} \#$ and $(i>) \ddot{a}>\bar{a} \#$; (3) diphthongization: a falling diphthong $\bar{\imath}>\bar{l}^{\ddot{u}} \#, \bar{u}>\bar{u}^{\ddot{a}} \#, \bar{o}>$ $\bar{o}^{\ddot{a}} \#$ and $\bar{e}>\bar{e}^{\ddot{a}} \#$; addition of final $w / y:-a>-a w \#,-u>-o w \#$ and $-i>-e y \#, \bar{e} y \#$; (4) raising of vowels $\bar{a}>\bar{s} \#$; and (5) aspiration where the word ends in short vowels and consonants: $(-i>)-e>-e h \#,-C \#>-C h \#$.

In this paper I intend to describe only further pausal forms which I recorded in Kuf ${ }^{u}$ rKanna and that do not occur in the Arabic of Nazareth. Thus this study is a complement to the other one on Nazareth. To the best of my knowledge the phenomena found here have not been documented anywhere in the area, i.e. in the Palestinian dialects. ${ }^{8}$ Thus the present paper is the first to examine this dialect with its documentation of interesting linguistic forms.

I conducted my fieldwork among a Muslim and Christian population in Kufur-Kanna, north of Israel. It consists of live recordings of informants who live in Kufur-Kanna, including especially extended, continuous texts of various types, which give a naturalistic representation of daily speech. The recordings contain stories, jokes, customs, life stories, etc. The informants were of various backgrounds (academics, high school graduates, and illiterate people) varying in age (young 15-25: 5 males and 5 females, middle-age 26-50: 5 males and 5 females, adults 50+: 5 males and 5 females) and gender. The overall length of the tape-recorded material amounts to approximately 5 hours.

It is assumed that the varied recorded texts will constitute an accurate representation of

4 The sign \# means pause here.

5 Cf. ZU'BI 2017.

6 Ibid., 163-167.

7 Ibid.

8 Some phenomena have been attested among Bedouins (see below). It is worth noting that the informants in this study are not of Bedouin origin. 
the dialect of the village that comes into daily use by the residents, especially when the recorded are natives of the village along with their parents and grandparents. These people speak the dialect of the village from birth, studied and worked there all the time and were usually not subject to external linguistic influences.

\section{Pausal forms in AKK}

In AKK pausal forms are common in the speech of middle-aged and elderly Muslims and elderly Christians similar to what is happening in Nazareth. ${ }^{9}$ The existence of the phenomenon among this age group is subject to various speculations. It can be assumed that the immigrants from Lebanon who came to the place brought with them this phenomenon in the past, which is also common in Lebanon (ZU'BI 2017: 167-168). This phenomenon has been preserved among the elderly to this day. Another possibility is the existence of the phenomenon originally in the village itself (ibid.) especially among the middle-aged and elderly whose language has started to have little effect over time on the young people who sometimes prefer the 'prestigious' forms. As is well known, young people are always subject to linguistic change as a result of their studies and work, especially outside the village (see details in $\S 4$ below).

In the speech of people in AKK words occurring in pausal position may undergo different kinds of changes according to the type of the final syllable. ${ }^{10}$ In AKK, we can distinguish two types of pauses: minor pause (short pause) in which one alternation occurs: changes in vowel quality such as lowering of short vowels, and a major pause (long pause) in which two alternations occur such as diphthongization where changes in vowel quality and the addition of a final consonant occurs. ${ }^{11}$

\subsection{In pausal position, the following further alternations occur in AKK}

3.1.1 Lengthening of short vowels $-C v>-C \bar{v} \#,-C v C>-C \bar{v} C \#$ in final position: ${ }^{12}$

a) Lengthening of normal and anaptyctic short vowels in final closed syllable $-\mathrm{CvC}$ :

Table 1

\begin{tabular}{|c|c|c|c|}
\hline vowels in context form & lengthening in pause & example & translation \\
\hline$-C i C$ & $>-C \bar{\imath} C \#$ & $\begin{array}{c}\text { mažllis }>\text { mažlīs } \# \\
\text { gid'r } r \text { gid' } r \#\end{array}$ & $\begin{array}{c}\text { 'council' } \\
\text { 'a pot' }\end{array}$ \\
\hline
\end{tabular}

9 On the origin of pausal forms in Nazareth see ZU`BI 2017: 167-168.

10 Cf. Nazarene Arabic in ZU`BI 2017.

11 On Nazarene Arabic see ibid. Cf. LEWIN 1969; PROCHÁZKA 2002, 2006.

12 Although this phenomenon exists elsewhere, this phenomenon has not been documented to date in Palestinian dialects and is therefore important to describe it here. Cf. also LEWIN 1969: 17; PROCHÁZKA 2002: 63; 2006; ZU`BI 2014: 109; EAD. 2017: 163-164; EAD. 2021: 326-327.

jaig • 21 (2021): 121-136 
My corpus includes examples with the short vowel $i(\mathrm{CiC})$.

\subsubsection{Devoicing of voiced consonants in word final position: ${ }^{13}$}

Voiced consonants, except the nasal consonants, become devoiced in word final position as in the following: ${ }^{14}$

\section{Table 2}

\begin{tabular}{|c|c|c|c|}
\hline consonants in context form & changes in consonants in pause & examples & translation \\
\hline$-C$ & $>C$ & 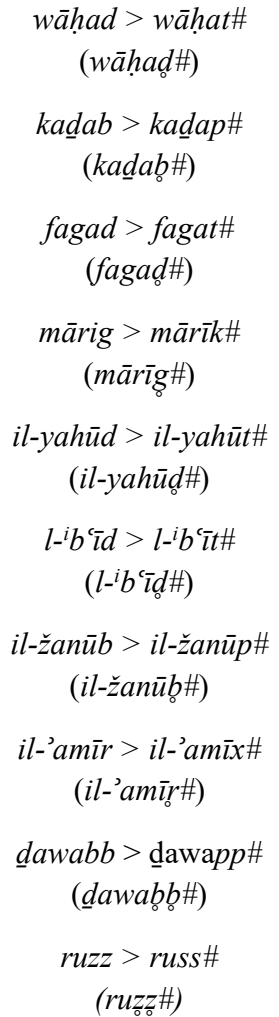 & $\begin{array}{l}\text { 'one' } \\
\text { 'he lied' } \\
\text { 'he lost' } \\
\text { 'who } \\
\text { passes/goes' } \\
\text { 'the Jews' } \\
\text { 'the distant' } \\
\text { 'the south' } \\
\text { 'the prince' } \\
\text { 'animals' }\end{array}$ \\
\hline
\end{tabular}

13 Cf. ARNOLD 2013. This phenomenon had been attested in the dialects of the Bedouin in Negev. Cf. BlanC 1970, II: 6; HENKIN 2010: 14. Part of the population of the village are Bedouins who immigrated to the village in the past. There is a neighbourhood there called the "Bedouin Neighbourhood." These Bedouins have linguistic features in common with the Bedouins of the Negev (for this see $\mathrm{ZU}^{\mathrm{C}} \mathrm{BI}$, forthcoming). In this article I only describe the phenomena that exist in the village. This article does not intend to discuss the source of the phenomena but some explanations are provided below. This topic will be reserved for future research.

14 Cf. JASTROW 1978: 98; ARNOLD 1998: 172, comment 327; PROCHÁZKA 2002: 63; 2006. It is reported for Bedouin dialects in Israel, see ROSENHOUSE 1984: 77. 
As mentioned above, this phenomenon has been documented among Bedouin in the Negev and in the north. As mentioned above, part of the population of the village is Bedouin immigrants living in their neighborhood. A logical explanation of the phenomenon is the effect of the Bedouin dialect on the dialect of the village elders. Moreover, the most logical is the explanation that only the elderly will be affected by this dialect which is considered non-prestige among the young people. We therefore find this phenomenon only among this age group.

The shift of $r$ to $x$ may be an influence of Hebrew, in which Hebrew speakers articulate $\dot{g}$ or $x$ instead of $r$. According to KREITMAN (2008: 121-122) in her experiment/study on Modern Hebrew: "initially $r$ was used as the voiced counterpart of $x ; r$ and $x$ are used for convenience for what is assumed to be uvular segments: $[x]$ being the uvular voiceless fricative and $[r]$ being a uvular segment. There is some evidence from child language acquisition that $r$ may be the voiced counterpart of $x$, based on confusion of the two phonemes. Moreover, based on evidence from Biblical Hebrew, it has been claimed that $x$ is a voiceless velar fricative and $r$ in MH is its voiced velar counterpart (BLANC 1964, CHAYEN 1972). Others claim that both $x$ and $r$ in MH are uvular (BERMAN 1997, BOLOZKY 1972 , 1978). In other words, both the place and manner of articulation of these two segments are disputed. While there is no debate that $x$ is a fricative, the nature of $r$ is not so straightforward. BolOzKY $(1972,1978)$ claims that $r$ is a uvular fricative while Berman (1997) claim that the MH $r$ is a uvular trill. In either case, $r$ behaves as a sonorant phonologically and therefore, cannot be used as the voiced counterpart of the uvular voiceless fricative $x$ ".

In light of the disagreement regarding the $r$, it is possible in our case to assume a Hebrew influence, since the informants are in daily contact with Hebrew speakers in all areas of life such as, work, studies, cultural life and more.

\subsubsection{Glottalization in word final position}

Glottalization after vowels and consonants in pausal positions in word final position:15

Table 3

\begin{tabular}{|c|c|c|}
\hline context form & change in pause & translation \\
\hline Kufir Kanna & $>$ Kufir Kanna \# & 'Kufur-Kanna' \\
\hline$i l-^{c} a d \bar{a} t$ & $>i l-^{`} a d \bar{a} t^{\prime} \#$ & 'the customs' \\
\hline
\end{tabular}

15 Cf. ARNOLD 2010: 232. This phenomenon had been attested in the dialects of Bedouin in Negev. Cf. BLANC 1970, II: 6; HENKIN 2010: 13.

• 21 (2021): 121-136 


\subsubsection{Aspiration $^{16}$}

a) Addition of $[h]$ occurs in pausal position where the word ends in long vowels. The addition may be accompanied by shortening the long vowel in the last syllable: ${ }^{17}$

Table 4

\begin{tabular}{|c|c|c|c|}
\hline vowels in context form & aspiration in pause & examples & translation \\
\hline$-\bar{u}$ & $>-\bar{u} h \#$ & $\check{s} \bar{u}>\check{s} \bar{u} h \#$ & 'what' \\
\hline$-\bar{l}$ & $>-i h \#$ & $\begin{array}{r}b t i \dot{g} l \bar{g} \dot{g} a l \bar{l}>b t i \dot{g} l \bar{l} \dot{g} a l i h \# \\
f \bar{l}>f i h \#\end{array}$ & $\begin{array}{c}\text { 'you boil him a lot' } \\
\text { 'there is' }\end{array}$ \\
\hline
\end{tabular}

\section{Origin of the pausal forms in AKK}

In Palestine some pausal forms are unique to Galilee. ${ }^{18}$ As stated in the paper about Nazareth, ${ }^{19}$ one possibility is that this phenomenon originated in the rural areas which surround Nazareth (such as Kufur-Kanna). ${ }^{20}$ Another interesting possibility is that this phenomenon may have originated in Lebanon and reached Galilee (especially Nazareth and the surrounding villages) by immigrants who settled there. ${ }^{21} \mathrm{~A}$ third possibility is that this phenomenon originated in the Arabian Peninsula and reached Kuf ${ }^{u}$-Kanna, Nazareth and other places by Bedouins who moved to Palestine and settled there. ${ }^{22}$ Another explanation may be that this phenomenon has always existed in the speech of the inhabitants of the region regardless of external influences, but no researcher has discovered it or written about it before. Thus, it may be that other regions and other groups are characterized by this phenomenon and therefore it is worth expanding the study of this phenomenon. I assume that this last option is the most logical in this context, but additional possibilities can also be raised for the spread of this phenomenon.

16 It is important to note that the $h$ in $f i h \#$ in the last example in the list is not an attached pronoun and this word differs from fih with the meaning 'in it, with it'.

17 This phenomenon had been attested in Bedouin dialects in Negev. Cf. HENKIN 2010: 14. Cf. also ARNOLD 2010: 232; ZU'BI, forthcoming. According to the behaviour of this dialect, we expect a diphthongization instead of an aspiration in the example $\dot{g} a l \bar{l}>$ \# $\dot{g}$ aliy vs. $\dot{g} a l i h \#$ just like Nazareth.

18 Cf. the pausal forms of Nazareth in ZU'BI 2017.

19 Ibid.

20 Cf. $\S 3$ above. See also ZU`BI 2017.

21 Cf. ZU`BI 2017.

22 See $Z U^{c} B I$, forthcoming. 
From the research I conduct in different areas of Israel, I meet different people from different areas. I found, for example, this phenomenon among some of my informants in the city of Acre whose dialect has not yet been studied. In my opinion, if a particular phenomenon has not been documented and/or a particular area has not been studied, it does not mean that the same phenomenon does not exist. Despite the many studies conducted in the past, there is still a lack of research in various parts of Israel. It is possible that in the areas studied so far no one noticed this interesting phenomenon and/or this phenomenon did not interest those researchers.

And to the question: why has this phenomenon been documented only among the elderly? It may be that at the time the entire population was influenced by the new dialect of the new inhabitants/immigrants. Apparently over time it is preserved only in the dialect of the old people, as the young people are prone to linguistic changes and are influenced by innovations in the field, they may prefer the 'prestige' of the language and it is not considered 'prestige' compared to different areas where this phenomenon does not exist.

\section{Summary and Conclusion}

The aim of this paper has been to describe the system of vocalic and consonantal variants in pausal positions pertaining to speakers of AKK and to determine the features that characterize the AKK in this regard.

In AKK, pausal forms occur in the speech of middle-aged and elderly Muslims and elderly Christians. In addition to changes in consonants and vowel quality in their speech, we have seen that in pausal position final syllables also undergo other modifications relative the form in contextual form. As stated earlier (see $\S 3$ above), common phenomena with the dialect of Nazareth were found here; these phenomena were mentioned in this article without detail (for details see $\mathrm{ZU}^{\mathrm{c} B \mathrm{BI}}$ 2017), e.g. the closed syllables often undergo only a change of vowel quality, but this may also be accompanied by lengthening (see $\S 3$ above); final open syllables have changes in vowel quality and secondary changes such as diphthongization (see $\S 3$ above). ${ }^{23}$

In the speech of Muslims and Christians, words occurring in pausal position may undergo different kinds of change according to syllable type.

The pausal forms described above are quite rare in Palestine. Till now only pausal final imāla a $>i>e$ had been attested in central Palestinian dialects. Glottalization and devoicing of consonants have been attested in Bedouin dialects in Negev. Lowering of short vowels, lengthening of sort vowels, diphthongization and aspiration have been attested lately in the Arabic of Nazareth, ${ }^{24}$ while other pausal forms that are documented in the current paper (such as of voiced consonants and glottalization) were hitherto unattested in Nazarene Arabic. Such forms which had been attested in Nazareth and Kufur-Kanna were hitherto unattested in other Palestinian places/dialects.

\footnotetext{
23 ZU'BI 2017.
}

24 Ibid.

jحis • 21 (2021): 121-136 
I believe that these issues are worth investigating in further places in Galilee rather than Nazareth and Kufur-Kanna. It would be also interesting to find out whether these features can be confirmed for other Arabic dialects in Palestine.

\section{Sample text ${ }^{25}$}

The informant is a Muslim, who was born in 1942 in Kufur-Kanna. He visited the elementary school in Kufur-Kanna. He is married and has many children. He cultivates his land. $\mathrm{He}$ is a kind and tactful spokesman who welcomed me at his house with great hospitality.

\section{Sample}

(1) $\underline{\text { talāte } w}$ 'ǐ̌rrīn xamse 'alf $w$ tis ${ }^{i^{i}}$ mīy $y i$ itnēn $w$ 'arb' ‘̈̈ $n$. 'assa 'il-... muškilitna 'ihna 'il-'istām 'Alla 'an'am 'alēna bfatrit il-'islām min'āmin bi-l-qaḍa ${ }^{26} w$ il-gadar wa-lākin 'atrakna l-'adāt ilhadīti $w$ iš-šarīfi $w$ il-karīme ${ }^{27} w$ 'ahdināha la-'ixwānna il-masiḥīye w ilyahūt. $w^{i}$ ttartahnna ${ }^{28}$ bi-l-'adāt illi miš 'ilna. bi-l-'awwal bagēna niktafi bi-lgalīl, ' inhibb ba'adna, 'it-ta'āxey, 'itta'āwun, 'ir-rgīif il-xubiz wāhat, kubbāyt il-mayy wahadi. 'il-kull minna ni'laf ba'edna w ni'man la-ba'edna.

(2) hatta miš žā.. miš 'axūy wala 'ammi wala xāley, ${ }^{29}$ žārak, žārak il-garīb wala 'axūk l-ib'ìt. l-íflāha hī 'izz 'ilna w karāme. w fì talāti bi-l-ḥayā la-r-

\section{Translation}

Twenty three, May 1942. As Muslims our problem is that God presented us in the Islamic era with a belief in fate and destiny. We stopped using the modern, honourable and decent habits and presented them to our Christian and Jewish brothers. We acted according to habits which are not ours'. In the past we were happy with little: We loved each other, there was fraternity and cooperation. The loaf of bread was one, the glass of water was one. We all were accustomed to each other and trusted one another.

Not even ... neither my brother nor my paternal uncle nor my maternal uncle, your neighbour, your foreign neighbour and not your distant brother. To us farming is power and dignity. And in life there are three $<$ im-

25 In dialectological studies the hamza ' is not transcribed, because according to its historical development it has fallen and disappeared from speech. In my text the hamza will only appear when it is articulated by the informant.

26 In his speech, the informant pronounces the $d$ as interdental $\underline{d}$ throughout the recording.

$27 i>e$ in this example since it is not an original $i$, i.e. $i(<i)=e y, i(<a)=e$.

28 This verb is used in Galilee in the sense of "feeling comfortable to use, to use a certain thing widely." The source of the verb can be the Arabic verb irtăha 'to feel comfortable' from the root $r w h$.

29 See footnote 27 above. 
Sample

ražul: 'ida kadabo, ${ }^{30}$ fagad 'arḍo $w$ 'arḍo w karāmto. w il-yōm 'il-kị̣ib malān. w il-mar'a 'ida kadbat, 'id $\underline{d} a$

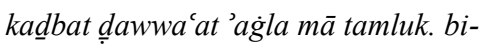
l-'awwal bagēna 'ala.... 'a-z-zirā'a, lihrāt 'il-bayādir, 'il-hașīdi w ni'tazz bhāy il-ḩayā. fa-hal-yōm fišš. bithibbi ad̄iflik 'uxra?

(3) Kufir Kanna bi-l-mādey balad min l¿blād il-mugaddasi w lā tazāl. bīžu min 'Amērka yzurūha, bī̌u min kull 'anḥa ' il-'ālam. fi gișşa 'illey 'il-masīh hawwal il-mayy 'ila xam ${ }^{\bar{e}} x$. 'ir-rìgif il-xub'z w (is)samaki 'aț'amu 'arb'inn. Kufir Kanna kānat bi-l-'awwal ḥawalēha badāwey, fi mantiga hōna bi-l-žanūbo isimha žabal Sìx sakanu fìha Zayādne w dabahu ah ${ }^{i l}$ Kufir Kanna garbīy il-'ên.

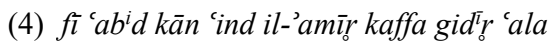
talat 'atfāl, w it-talat atfāl hinni raddow žaddadūw 'êlt il-'Amāra. w wāhad țabb bi-l-zayādney šarg il'Urdun w intašrat. Kufir Kanna kānat bi-l-mi'āt, 'il-yōm hawēla xamsa w 'išrīn 'alf. bir'asha mažlis w il-'amal tithawwal la-baladīyi w inšăll la bukūnow 'ir-ra's̄s il-ḥāley 'inšātlḷa bukūn fāliḥ w bikammil mišwāru bi-lxēr wil-barakey.

(5) 'ēn Kufir Kanna 'ịnna bagēna sāknīn ${ }^{31}$ žirān il-'èn w là yazāl 'ịnna žirān il-'ēn min šarga. 'ēn Kufur

\section{Translation}

portant things $>$ for man: If he lies, he will lose his land, his honour and his dignity. And today lying is much. And if the woman lies, if she lies, she will lose the most expensive $<$ thing $>$ she has. In the past we $<$ relied $>$ on agriculture, ploughing, threshing floors, harvest and we were proud of this life. But today $<$ these things are $>$ not here $<$ i.e., do not exist any longer $>$. Would you like me to add something? In the past, Kufur-Kanna $<$ was $>$ one of the holy villages, and it still is. They $<$ i.e., visitors $>$ come from America to visit it, they come from all over the world. There is a story that $<$ here $>$ Jesus turned the water into wine. The loaf of bread and the fish fed forty $<$ people $>$. In the past there were Bedouins $<$ who lived $>$ around Kuf ${ }^{\mathrm{u}} \mathrm{r}$-Kanna, here in the south there is an area called 'Ǧabal Sīx'. Zayādne lived in it and killed the people of Kufur-Kanna to the west of the spring.

There is a slave who was $<$ i.e., served $>$ the prince, he presented a pot of food to three children, and the three children renewed the family of Amāra. And one went to the Zayādne $<$ family $>$ in the east of Jordan which $<$ then $>$ expanded. Kufur-Kanna had hundreds $<$ of people $>$; today $<$ it contains $>$ about twenty five thousand. It is headed by a council and we hope that it will become a municipality and we hope that they will .. we hope $<$ that $>$ the current head $<$ of the council $>$ will be successful and continue his good and blessed way.

$<$ Regarding $>$ the well of Kufur-Kanna: we came to live near the well and we are still $<$ living $>$ near the well to the east. In the past, $<$ the people $>$ and the herd

30 The informant makes a pause here.

31 It is probably a Standard influence: $\bar{a}$ instead of $a$ in the first syllable: sāknīn vs. saknīn.

ز 21 (2021): 121-136 
Sample

Kanna bi-l-māḍey kānu yišrab(!) minha Kufur Kanna w halāl Kufur Kanna, 'il-Hēbo, 'il-Mišhad tīži tišrab minha. 'il-yōm xirbat $w \underline{d} \bar{a} \bar{a}^{c} a t$, dawwa'atha Makarōt ${ }^{H 32}$ w ir-ra'īs ilžāy w illi maḍa willi gablu w illi gablu. 'il-yōm fišši 'èn. mayyitha kānat tisgey rummān Șaffūrye, mayyit Kufir Kanna. 'il-yōm fišš. mašhūra bi-r-rummān, na'am w lā yazāl rummān... fì mațal rummān Kufur Kanna Slā yu'la 'alēes ${ }^{33} w$ zitāt Kufur Kanna slā yu'la 'alēhins.

(6) lamma ḥtallu l-Yahūd 'ana baga 'umri sitt $^{i}$ snīn. hayāt sīdey mn il-fallah̆lü $n$ ilmašhurï̄̈n. $w$ 'indu hawēla i išrīn rās bagar. ḍarbat il-midfac ind il-Mišhad, 'ah'l Kufir Kanna gabbat. gabilha byumēn kānu ș-Saffäfre hažžīn. xallu 'ind dār 'abūy 'arba' $x a m^{i}$ s dawabb. lamma hažžat Kufir Kanna wazza'hin 'abūy lașhābu la-ṣhābu w ihna hammalna w nzilna 'a-l-i 'Zēr. hayāt sīdi gallhin 'ana biddi 'amūt 'ana witt-taršāt hōn. biddī̌s yōklūhin ${ }^{35}$ klāb Rabb il-'ālamīn b-žabal Tur'ān. sakkar il-bāb 'alēhin, w'abūy w i'māmey šammalu 'a-l- 'ं'Zēr.

(7) 'ahil l-i'Zēr ixwālu la-būy, kaffalu l-

\section{Translation}

of Kufur-Kanna used to drink from the well of Kuf ${ }^{u}$ rKanna, $<$ and also $>$ the Hēb, Mišhad used to come $<$ and $>$ drink from it. Today it is spoiled and lost. Makarō $t^{34}$ spoiled it as well as the current head, the former $<$ head $>$, the previous $<$ head $>$ and $<$ also the head $>$ who preceded him. Today there is no spring. Its water was used to irrigate the pomegranates of Zippori, $<$ i.e. $>$ the water of Kufur-Kanna. Today $<$ there $>$ is no $<$ well $>$. $<$ Kufur-Kanna $>$ is known for its pomegranates. Yes the pomegranates still $<$ exist there $>$... That is a saying $<$ that $>$ there are no pomegranates better than those of Kufur-Kanna, and there is no olive oil better than that of Kufur-Kanna.

When the Jews occupied $<$ the region $>$, I was about to become six years old. My late grandfather $<$ was $>$ one of the famous farmers. He had about twenty cows. $<$ When $>$ the cannon fired on Mišhad, the people of Kuf ${ }^{u}$ r-Kanna were afraid. Two days before, the Șafăfre ${ }^{36}$ fled. They left four $<$ or $>$ five animals at my father's house. When $<$ the people of $>$ Kuf ${ }^{u}$ r-Kanna fled, my father distributed them (= the animals) among his friends and we departed to $1-^{\mathrm{i}}{ }^{\mathrm{i}} Z \overline{\mathrm{e}}$. My late grandfather said to them, "I want to die with the animals here. I do not want that the dogs of God eat them in the mountain of Țur ān. He closed the door on them, and my father and my uncles went north to 1icZēr.

The people of 1-ic Zēr are the maternal uncles of my

32 The superscript H means "Hebrew".

33 The superscript S means "standard Arabic".

34 I.e., the Israeli water company.

35 According to the behaviour of this dialect, we expect the short vowels $u$ or $o$ instead of the long vowel $\bar{o}$ in the first syllable: yōklūhin vs. yuklühin, yoklühin.

36 I.e., the people of the 'Șafāfre' neighbourhood in Nazareth who fled from Zippori when the Jews came. Afterwards they came and are settled till now in Nazareth. 
Sample

'byāra. wahade 'asāsha tur'anīye b${ }^{\prime} i{ }^{i} m$ 'Alya t-Tubbal kaffalat l-ibyāra. kān mac... xalla'u l- $^{i}$ gfāl l- ${ }^{i}$ gfüli hayāt 'abūy w xāley 'abu 'Ursān Lāfi. ${ }^{3}$ nzilna tị̆t iz-zatūn. țāni yōm nizil wāhad min žamā't illi sakkart l- ${ }^{i}$ gfūli, 'illi hū 'Ali l-Gìyam 'abu Hsēn. gallu ya xāli hū 'intu hōn. hā $\underline{\underline{d}}$ l-māris 'ašara xam ${ }^{i}$ sțāšar dulum ${ }^{3 i}$ sbìl la-'ah'l Kufir Kanna. ga'adna yumēn talātey, 'aža hayāt 'abūy fagad hōn bi-l-balad gāl fišš išey hammalna $w$ ḍallēna $\operatorname{räz} \bar{z}^{\top} \bar{i} .^{37}$

(8) 'írās zamān kānow in-nās haḍāk min haḍāk illi yž̄ib haddāyi. kānu n-nās yi'malu l-'urs ' $a$-smīdey w il-nādīr illi yhuțtu russ zayy iṣ-ṣnōbar il-yōm $w$ ywazz ${ }^{c} \bar{u}$ 'a-l-maḍafāt. fa-l-yōm șārat in-nās titšābah, 'illi ma'ā willi mā ma'u biddu yi'mal 'urs $w$ nitsābagu mīn 'ursi 'akbax w mìn bid bah 'aktar

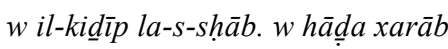
bë̈ $\bar{e}^{a}$. fi ktīir mn illi bitžawwazow bīži la-wlādhin wlāt $w$ id-dèn rakibhin $w$ illi 'indu šagfit 'arḍ bibīcha w bigatțĭšs hāalu.

(9) 'an tarīg il-'abb wil-'amm wilxāl. miš mițl il-yōm 'illa ma yug'ud ma'āha w tug'ud ma'ā. 'ana li-l-'abit hayāt mart xāley 'an tāni tạăbig nādat 'alayyi willa

\section{Translation}

father. They took care of the wells. $<$ There was $>$ a woman, whose origin is from Țur'ān, called 'Alya țTubbal, she took care of the wells. $<$ There $>$ was with... my father and my maternal uncle, called Abu 'Ursān Lāfi, removed the lock. We went down under the olive grove. On the second day one of the people who removed the locks came, who is 'Ali l-Giyam Abu Ḥsēn. He said to him, "my uncle, are you here?" This land is ten $<$ or $>$ fifteen acres for the people of Kufur-Kanna. We stayed two <or $>$ three days. My late father came and took stock of the village $<$ then $>$ he said $<$ that $>$ there was 'nothing', $<$ so $>$ we collected ourselves and returned.

In the weddings of the past, a few people brought had$d \bar{a} y i{ }^{38}$ People used to present $s m \bar{\imath} d i^{39}<$ to the visitors $>$ at the wedding, and $<$ it was $>$ rare $<$ that there was someone $>$ who put rice $<$ on it $>$, like pine nuts today, and they $<$ used to $>$ distribute them to the visitors. Today people are similar. $<$ The one $>$ who has $<$ money $>$ and $<$ the one $>$ who has no $<$ money $>$ want to arrange a wedding and they compete who $<$ will arrange $>$ a bigger wedding and who will slaughter more $<$ than the others $>$ and the lying $<$ reaches $>$ the clouds. ${ }^{40}$ And this is destructive. Many marry $<$ and $>$ after their children have children they $<$ still $>$ have a debt, and $<$ even the one $>$ who sells a plot of land cannot pay off the debt.

By means of the father, the paternal uncle and the maternal uncle. Dissimilarly, today he must meet $<$ lit., sit with $>$ her and she $<$ must $>$ meet $<$ lit., sit with $>$ him. I am the servant, my late uncle's wife from the second floor called me and said to me, "that <one>". I did not know

37 It is probably a Standard influence: $\bar{a}$ instead of $a$ in the first syllable ( $r \bar{a} z z^{c} \bar{i} n$ vs. $r a z z^{c} \bar{i} n$ ).

38 I.e., Arab folk singer.

39 I.e., semolina.

40 I.e., too much.

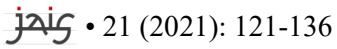


Sample

bitgulli had̄īk. ba rifhā̄s. 'ažìt bidd oxid 'axūha w ni ${ }^{c} z i m$, 'axūha $\underline{t}-\underline{t} \bar{t} n i$ bugullha hāḍa 'arīsik. daššarat satl il-mayy w inhazmat. w hēk kanat. lä kanu yi ${ }^{\text {i }}$ rfu yit ${ }^{c}$ arrafu 'ala ba'aḍin wala haddī wala waddī. 'ala sìt il-'imm wil-'abow wil-'èle, 'il-'êle. lamma fì 'inwān fišš ta'ab. baga l-yōm bit'arrafow 'a-t-talaföön $w$ il-'antarnet ${ }^{E} w$ hāḍa marfūt. w illi biži... whu 'illi bižīb il-mašākil w iṭ-țalāk w hatta l-firāg gabil b-fatrit il-xuțūbe hayḍa hay il-'umūr hī.

(10) ma-kanatš tgūl la'. 'à tgūl la'. 'ā walākin nādīro nādir illi titbažžaž w tgūl la', 'innu ma biddī̌s hāy iž-žízi. la', 'ihtirām la-l-'abā'. bi-l-'awwal yilizmūha, w hāḍa xața's. 'ana 'a'tarif

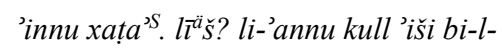
giwwi ma buzbut' 'š. 'ana bahibbiš bint 'ammey, lēš tannu 'altzim fìha, līüšs? 'id a fi šàin fa-l-yakun. 'amma la' kānu 'êš. fi matal 'ibn il-'amm binazzilha 'an il-faras. whāda galat. 'ana 'a'tarif ’innu galat. tixtāx, tixtār illi binasibha.

\section{Translation}

her. $<$ When $>$ I came to take her brother $<$ with me in order $>$ to invite $<$ people to the wedding $>$, her second brother said to her, "that $<$ one $>$ is your bridegroom". She set down a pail of water and then ran away. And it was like this. $<$ In the past $>$ they did not know $<$ or $>$ were not introduced to each other and anything. $<$ It was $>$ based on the renown of the mother, the father and the family, the family. When there is an address, ${ }^{41}$ then it would not be difficult. Today they introduce themselves by the telephone and the internet and this is unacceptable. And $<$ the thing $>$ which... and this creates the problems and the divorce and the separation even before $<$ the marriage, i.e. $>$ during the engagement period, these are the things $<$ today $>$.

The bride did not say, "no". Yes, < sometimes $>$ she said "no". Yes, but it was so rare that she refused and said, "no", that "I do not want this wedding". No, in respect of fathers. In the past they <used to $>$ force her, and this was wrong. I admit that it was wrong. Why? because everything $<$ that comes $>$ by force will not succeed. I do not love my cousin, why must I marry her, why? If there is an interest $<$ for me to marry my cousin $>$, it is ok. But no, they were... there is a saying, "the cousin drops her off the horse". But this is wrong. I admit that it is wrong. $<$ I think she should $>$ choose, choose $<$ the one $>$ who fits her.

41 I.e., established family. 


\section{Bibliography}

ARNOLD, Werner. 1998. Die arabischen Dialekte Antiochiens. Wiesbaden: Harrassowitz.

— . 2010. "Pausalformen in den arabischen Dialekten Antiochiens." In TALAY \& BoBZIN (eds.) 2010: 227-235.

— . 2013. "The Arabic Dialect of Isdūd (today Ashdod).” In Hussein (ed.) 2013: 268-272.

—, and Peter BehnSTEDT. 1993. Arabisch-Aramäische Sprachbeziehungen im Qalamūn (Syrien). Wiesbaden: Harrassowitz.

Awawde, 'Amir. 2008. Kafr-Kanna: Tārīx wa-turāt. Kafr-Kanna: Mațba'at Dār al-Hikma.

BAUER, Leonhard. 1913. Das palästinische Arabisch: Die Dialekte des Städters und des Fellachen. 4. Aufl. Leipzig (2nd version 1926).

-. (1933, 1957). Deutsch-Arabisches Wörterbuch der Umgangssprache in Palästina und im Libanon. Wiesbaden: Harrassowitz.

BehnstedT, Peter. 1982. "Die ägyptischen Oasen: ein dialektologischer Vorbericht." Zeitschrift für arabische Linguistik, 8: 39-71.

— 1985. Die nordjemenitischen Dialekte. Teil 1: Atlas. Wiesbaden: Harrassowitz.

—. 1992. "Zur Spaltung von *ā in ō/ē im Qalamūn (Antilibanon).” Die Welt des Orients, 23: 77-100.

- . 1997. Sprachatlas von Syrien: Kartenband. Wiesbaden: Harrassowitz.

—, and Manfred Woidich. 1985. Die ägyptisch-arabischen Dialekte. Bd. 2: Dialektatlas von Ägypten. Wiesbaden: Harrassowitz.

BERgSträsser, Gotthelf. 1915. Sprachatlas von Syrien und Palästina. Leipzig: Hinrichs.

Berman, R. 1997. “Modern Hebrew.” In Hetzron (ed.) 1997: 312-333.

BIRKELAND, Harris. 1940. Altarabische Pausalformen. Oslo: I Kommisjon hos Yacob Dybwad.

Blanc, Haim. 1953. Studies in North Palestinian Arabic: Inquiries among the Druzes of Western Galilee and Mt. Carmel. Notes and Studies. Jerusalem, The Israel Oriental Society.

— . 1964. "Israeli Hebrew Texts." In Rosen (ed.) 1964: 132-152.

Bolozky, S. 1972. Categorical Limitations on Rules in the Phonology of Modern Hebrew. Ph.D. Dissertation, University of Illinois.

— . 1978. "Word Formation Processes in the Hebrew Verb System: Denominative Verbs." Afroasiatic Linguistics, 5: 1-26.

Borg, Alexander. 1977. "Reflexes of Pausal Forms in Maltese Rural Dialects?" Israel Oriental Studies, 7: 211-225.

CAntineau, Jean. 1960. Études de linguistique arabe. Paris: Klincksieck.

Chayen, M. J. 1972. “The Accent of Israeli Hebrew.” Leshonenu, 36: 212-219, 287-300.

Clermont-Ganneau, Charles. 1899. Archaeological Researches in Palestine during the years 18731874. London.

Cleveland, Ray. 1967. "Notes on an Arabic Dialect of Southern Palestine". Bulletin of the American Schools of Oriental Research, 185: 43-57.

Cottrell, Alvin J. (ed.). 1980. The Persian Gulf States: A General Survey. Baltimore: Johns Hopkins University Press.

Cowell,W. Mark. 1964. A Reference Grammar of Syrian Arabic (based of the dialect of Damascus). Washington, D.C.

jix • 21 (2021): 121-136 
DrIVER, Godfrey Rolles. 1925. A Grammar of the Colloquial Arabic of Syria and Palestine. London: Probsthain.

Elitzur, Yoel. 2009. Ancient Toponyms in the Land of Israel (in Hebrew). Jerusalem: Yad Ben-Zvi Press.

FISCHER, Wolfdietrich, and Otto JASTROW (eds.). 1980. Handbuch der arabischen Dialekte. Wiesbaden: Harrassowitz.

FLeISCH, Henri. 1961. Traité de la philologie arabe, I. Beyrouth: Dar el-Machreq.

— . 1974. Etudes d'arabe dialectal. Beyrouth: Dar el-Machreq.

GARBELL, Irene. 1962. Review of: KUTSCHER 1959, Leshonenu 26: 140-46 (in Hebrew).

GrotzFeld, Heinz. 1964. Laut- und Formenlehre des Damaszenisch-Arabischen. Wiesbaden: Harrassowitz.

— . 1965. Syrisch-Arabische Grammatik (Dialekt von Damaskus). Wiesbaden: Harrassowitz.

—. 1980. "Das syrisch-palästinensische Arabisch." In FISCHER \& JASTROw (eds.) 1980: 174-189.

Havelova, Andrea. 2000. Arabic Dialects of Nazareth: A Dialectological and Sociolinguistic Description. Unpublished Dissertation Submitted for the Degree Doctor of Philosophy, University of Haifa.

Henkin, Roni. 2010. Negev Arabic: Dialectal, Sociolinguistic and Stylistic Variation. Wiesbaden: Harrassowitz.

Hetzron, Robert (ed.). 1997. The Semitic Languages. New York: Routledge.

Holes, Clive. 2004. Modern Arabic: Structures, Functions and Varieties. Rev. ed., Washington, DC: Georgetown University Press.

Hopkins, Simon. 2012. "Notes on the History of the Arabic Language in Palestine." In TAKASHINA et al. (eds.) 2012: 50-73.

Hussern, Ali (ed.). 2013. Branches of the Goodly Tree: Studies in Honor of George Kanazi. Wiesbaden: Harrassowitz.

IngHAM, Bruce. 1980. "Languages of the Persian Gulf”. In Cottrell (ed.) 1980: 314-33.

JASTROW, Otto. 1978. Die mesopotamischen qaltu-Dialekte. Bd. 1: Phonologie und Morphologie. Wiesbaden: Harrassowitz.

—. 1980. “Die Dialekte der arabischen Halbinsel.” In FisCHER \& JASTROw (eds.) 1980: 103-139.

JiHA, Michel. 1964. Der arabische Dialekt von Bišmizzīn. Beirut: Orient-Institut (in Kommission bei Ergon-Verlag, Würzburg).

Johanson, Lars, and Bo Utas (eds.). 1994. Arabic Prosody and Its Applications in Muslim Poetry. Stockholm: Almqvist and Wiksell International.

Kreitman, Rina 2008. The Phonetics and Phonology of Onset Clusters: The Case of Modern Hebrew. Dissertation Presented to the Faculty of the Graduate School of Cornell University in Partial Fulfillment of the Requirements for the Degree of Doctor of Philosophy.

KUTSCHER, Edward Yechezkel. 1959. The Language and Linguistic Background of the Isaiah Scroll. Jerusalem: Magnes Press. (In Hebrew).

KUTY, Renaud, Ulrich SEEGER, and Shabo TALAY (eds.). 2013. Nicht nur mit Engelszungen: Beiträge zur semitischen Dialektologie. Festschrift für Werner Arnold zum 60. Geburtstag. Wiesbaden: Harrassowitz.

LewIN, Bernhard. 1966. Arabische Texte im Dialekt von Hama. Mit Einleitung und Glossar. Beirut: Orient-Institut der Deutschen Morgenländischen Gesellschaft / Wiesbaden: Harrassowitz. (= 
Beiruter Texte und Studien, Band 2).

— . 1969. Notes on Cabali: The Arabic dialect spoken by the Alawis of "Jebel Ansariye". Stockholm: Almqvist and Wiksell.

Mion, Giuliano. 2008. "Le patah furtivum en sémitique: Remarques de phonétique et phonologie." Studi Magrebini, 6: 203-12.

ProchÁzKA, Stephan. 2002. Die arabischen Dialekte der Çukurova (Südtürkei). Wiesbaden: Harrassowitz.

— . 2006. "Cilician Arabic". Encyclopedia of Arabic Language and Linguistics, vol. I: A-Ed, LeidenBoston: Brill, 388-397.

RETSÖ, Jan. 1994. "The Treatment of Final Syllables in the Classical Arabic Metres: The Linguistic Background.” In JOHANSON \& UTAS (eds.) 1994: 99-106.

Rosen, Haiim B. (ed.) 1964. Studies in Egyptology and Linguistics in Honor of H. J. Polotsky. Jerusalem: The Israel Exploration Society.

Rosenhouse, Judith. 1984. The Bedouin Arabic dialects: General problems and a close analysis of North Israel Bedouin dialects. Wiesbaden: Harrassowitz.

Shachmon, Ori. 2011. "Pausal Final Imāla in Central Palestinian Dialects". Jerusalem Studies in Arabic and Islam, 38: 145-161.

— . 2013. "'ala fūk rōsi - 'on top of my head': The Shift of $\bar{a}>\bar{o}$ in a Palestinian Dialect." In KUTY, SEEGER and TALAY (eds.) 2013: 323-32.

SīBAWAIHI. 1881-1889. Le Livre de Sîbawayhi: Traité de grammaire arabe. Texte arabe publié par H. Derenbourg. 2 vols. Paris.

TAKASHINA, Yoshiyuki [et al.] (eds.). 2012. Toward Hetero-Symbiosis and Tolerance: LinguaCulture Contextual Studies in Ethnic Conflicts of the World. Lahore: Sang-e-Meel Publications / Osaka: Osaka University, Research Institute for World Languages.

TAlay, Shabo, and Hartmut BobZIN (eds.). 2010. Arabische Welt: Grammatik, Dichtung und Dialekte. Wiesbaden: Harrassowitz, 227-235.

WIKIPEDIA. "Kafr-Kanna." <https://he.wikipedia.org/w/index.php?title=eכo_oldid=32630917> (text subject to CC-BY-SA, <https://creativecommons.org/licenses/by-sa/3.0/deed.he>).

ZU'BI, Amal. 2014. The Arabic Dialects of Nazareth and the Surrounding Villages: Phonology, Morphology and Texts. Unpublished Dissertation submitted for the degree of Doctor of Philosophy, The Hebrew University of Jerusalem (In Hebrew).

—. 2017. "Pausal forms in the Arabic of Nazareth." Mediterranean Language Review, 24: 159-174.

- . 2021. "Some Remarks on the Arabic Dialects of 'Ar'ara in the Triangle Region (al-Mutallat )." WZKM, III, 311-350.

— . (forthcoming). "Sedentary and Bedouin Dialects in Contact: Remarks on the Dialect of Christians and Muslims in Kufr-Kanna." JSS [in print].

Zurub-Kawar, Nuha. 2000. The History of Nazareth: A Journey across the Ages. Nazareth (In Arabic).

(C) Amal Zu'bi, Hebrew University, Jerusalem

४amal.zubi@mail.huji.ac.il 